\title{
Exploring key competencies sought to potentialize tactical behavior in soccer players
}

\author{
GRÉGORY H. PETIOT'1 | DAVI SILVA² | LUCAS OMETTO²
}

\author{
1 Laval University, Quebec, Canada. \\ 2 Post-Graduate Program in Exercise and Sport Sciences, Laboratory of Soccer Studies, University of the State of Rio de Janeiro, Rio de Janeiro, RJ, Brazil. \\ Correspondence to: Grégory Halle Petiot, MSc, M. A. Rue de la Terrasse, Québec, Canada, G1V 0A6. Contact: +1 438 863-9303. \\ email: ghpetiot@icloud.com \\ https://doi.org/10.20338/bjmb.v14i5.199
}

\begin{abstract}
HIGHLIGHTS
- Tactical competencies such as intelligence, creativity, and adaptability can give an individual and collective competitive advantage.

- Intelligence and creativity complete one another as they lead players to find solutions to the play's problems in two different ways.

- Competencies will solicit cognitive skills but will mainly arise if compatible possibilities are offered in the play.

- Small-sided and conditioned games are ideal exercises to develop the competencies as long as they are configured accordingly.
\end{abstract}

\section{ABBREVIATIONS \\ SSCGs small-sided and conditioned games}

PUBLICATION DATA

Received 24092020

Accepted 28102020

Published 01122020

\begin{abstract}
BACKGROUND: Soccer is part of the team sports games category and is characterized by the cooperation and opposition interactions between players in the same space of play and time. Thus, players must adequately decide what action to perform despite the unpredictable, random, and varying nature of the environment of play. AIM: This paper explores tactical competencies that can be appreciated in the way players play and their functioning.

METHOD: The argumentation is structured over a review of sixty articles in five languages, selected from the results in an online university library with topic-related keywords. The selected papers were analyzed to identify the most frequently reported concepts related to (i) tactics and action in the play; (ii) decision-making and associated cognitive mechanisms and skills; and (iii) the teaching-learning-training process.

RESULTS: The results of this review sum the three following competencies: tactical intelligence, creativity, and co-adaptability. We argue that these competencies can be built through the play's practice and that coaches should seek to use them to the advantage of player's development. Small-sided and conditioned games reflect a compatible opportunity to nurture the competencies as long as they are configured to solicit the competencies in an environment that promotes them.

CONCLUSION: Tactical intelligence, creativity, and co-adaptability can be appreciated in the tactical behavior shown by performing players. For the same reason, those also should constitute more of the player's development curriculum, therefore leading to players who have a competitive advantage.
\end{abstract}

KEYWORDS: Performance | Tactics | Team Sports | Sport Science

\section{INTRODUCTION}

Soccer is part of the team sports games category and is characterized by the cooperation and opposition interactions between players in the same space of play and time. ${ }^{1}$ Thus, players must adequately decide what action to perform despite the unpredictable, random, and varying nature of the environment of play. 2,3 Moreover, players must perform actions in line with the objectives inherent to the play's situations to reach positive results with their team. For this reason, the tactical dimension of the game is considered essential in the success of teams and players. ${ }^{4}$ Thus, according to various concepts presented in the literature, the idea of management through positioning and movement of players reflects the competencies that players and teams must develop to perform in the context of the play. ${ }^{5}$

The challenge lies in making the best decisions and providing the most beneficial outcome for the play. Generally, tactical actions are qualified as both efficient and effective if their results are positive, and their execution are good. ${ }^{4}$ In fact, the efficiency and effectiveness of these actions portray how well players respond to situations in the play, which can reflect their competencies.

According to Garganta and colleagues, ${ }^{6}$ competencies are skillsets and attitudes that help solve situations and the skills associated with the task at hand. For example, players must develop competencies associated with (1) the reading and interpretation of

\begin{tabular}{l|l|l|l|lc}
\hline $\begin{array}{l}\text { Petiot, Silva, } \\
\text { Ometto }\end{array}$ & 2020 & VOL.14 & N.5 & https://doi.org/10.20338/bjmb.v14i5.199
\end{tabular}


emerging problems in the game and (2) the choice of the possibilities of actions. ${ }^{7,8}$ It was shown that such competencies bring more quality to individual and collective behavior in the play as much as they help players take advantage of the appropriate options and consequently give a clear advantage to the team. ${ }^{4}$

These competencies have mainly been associated with cognitive skillsets. However, contemporary literature highlights the importance of actions that emerge in players' play and their involvement. Therefore, the key tactical competencies must be developed, focussing on individual progress as much as on the offered environment, or more specifically on the situations of play. The combination of the changes in both the individuals and the context throughout the long-term player development is sought to solicit the development of the play's reading, problem-solving and adaptation.

This review article aims to explore tactical intelligence, creativity, co-adaptability, and self-organization as tactical competencies that are increasingly associated with good decision-making in the play as well as to performing outcomes for teams. We have reviewed sixty scientific articles amongst the research results in scientific databases to identify the important elements of decision-making. Various searches in the Laval University article database were pursued using decision-making and tactics as primary keywords, in addition secondary keywords were used such as knowledge, learning, or development, in five languages. The selected articles were published between 2001 and 2020 and covered a combination of, if not all, some of the following topics: (i) tactics and action in the play; (ii) decision-making and associated cognitive mechanisms and skills; and (iii) teaching-learning-training process. We present our results as a narrative review that discusses the competencies and qualities identified in the literature.

We hypothesize that, in addition to optimizing the decisional process in the play, the tactical competencies influence the tactical behavior of players. Also, they help practitioners to identify the competencies in the performance on the field when scouting and training. Therefore,suggestions and clarifications in this matter may also provide more guidelines for soccer development. Pursuing the aim to provide experts' intuitive, experiential and explicit perspectives in focused topics about the cognitive approach to decision-making in team sports, ${ }^{9}$ we opted for a narrative review that revisits the theoretical framework of decision-making and pinpoints emerging hints of the influence exercise by the specific context of play on the decisional process on the development of intelligence, creativity, and co-adaptability.

\section{KEY TACTICAL COMPETENCIES IN TEAM SPORTS GAMES}

Regarding tactics the aimed outcome of decisions is the intention of actions - often referred as "what to do". ${ }^{10}$ The choice of the action could be based on the reading of the play through the recognition of patterns. ${ }^{11,12}$ Competencies could also embed abilities helping players accurately and adequately process the perceived information so that the decision brings efficient outcomes. That is the perceived information from the environment like score, time, strength, and weaknesses. ${ }^{13}$ The play is the context that encompasses the most repeated stimuli and demand to read and decide "what to do".

The idea of using the game itself to fuel tactical competencies reinforces the dominance of tactics regardless of the level of complexity of the organization that the coach wants to achieve. ${ }^{14,15}$ More importantly, modifying the game also brings players to implicitly develop and adapt to different degrees of freedom while training under the 
game's variants. ${ }^{16,17}$ In brief, we use small-sided and conditioned games (SSCGs) as one of the most representative alternatives to stimulate tactical competencies since they offer repetition despite the unpredictability, variability, and randomness nature of the play. ${ }^{18}$ Exposing players to a higher experience of practice activities involving decision making facilitates the transfer of skillsets and learning to the formal game. ${ }^{19}$ Whether it is to structure a whole team or improve a player's individual capability, these games also provide the most relevant, significative, and representative stimuli to develop competencies, especially the tactical ones. When linked throughout the cooperation of competent players, these assets will give teams a competitive advantage that will be reflected in better synchrony, organization, and probably a better outcome.

This section covers three competencies that are often mentioned and described in the literature about decision-making and team sports performance. These competencies are explored to illustrate how they help players execute efficient and effective tactical actions, taking various examples of experts' performances. Tactical intelligence, creativity, and co-adaptability can always be associated with general abilities demonstrated in the play as players are acquiring skills, developing their own identity and strengths through the experience of various situations of play. However, in this review, the selected competencies were reviewed assuming they encompass the skills that are solicited during the decisional process and, consequently, observed in the players' movement and positioning. Given the dominance of the game's tactical nature, these competencies can give consistency in respect to both the choice and execution of action inclusively in a very competitive environment.

\section{Tactical intelligence}

Intelligence is mostly associated with problem solving. ${ }^{10}$ Reasoning, planning, understanding, learning, and adapting to different contexts are all demonstrated through intelligent solutions, in and out of the sport context. These are all processes required by individuals in general as they face obstacles, and they are all developed through adolescence. Intelligence is relevant in team sports since problems are referred to as situations of play and must be solved performing better positioning and movement. To perform intelligently, individuals must then rely on the ability to read the play and interpret it first to identify the exact problem to solve and have the right intention when choosing the action that should solve the problem. 8,20

As intelligence is often associated with knowledge, the belief that players could decide better if they knew more could incentivize coaches to teach more. ${ }^{19}$ Still, according to these authors, intelligence also refers to the quality of information used to make the decisions. In such a case, the information that should be captured from the play, under time pressure, is still mainly frugal. ${ }^{21,22}$ Plus, knowledge will rather be built in the form of implicit experience of the play ${ }^{23,24}$ and habits ("habitus") 25 that allow players to perform efficiently, effectively, but mostly instantaneously. Accordingly, technical skillsets are also an important condition for tactical decisions since knowing-how allows better players to make decisions that others would not have the confidence to execute successfully. Hence, it is likely that young players resort to technical resources and skills learned through drills or that they have been rehearsing by themselves since they feel more immediately effective to them. ${ }^{26}$ In sum, intelligence does build on knowledge but still has to match the play's ecological reality and the functioning of decision-making. For this reason, 
intelligence will arise with the ongoing and repeated experience of the specific context and its constraints, without pulling the tasks out of it.

Intelligence also spans factors and processes associated with performance. Considered as a factor affecting cognition and decision-making, ${ }^{27,28}$ emotions should be controlled to help attention and perceptual-cognitive perform the most effective as possible to solve problems through training. ${ }^{29}$ This type of training can help control players' impulsive decisions and stick to an agreed game model and strategy. ${ }^{30}$ In line with this enhancement, emotional intelligence should be developed through higher performance training programs as more sources of influence may affect performance, such as the feedback provided by spectators and medias. ${ }^{31}$

In practical terms, players must test out, experiment with consequences, and learn from decisions in a wide variety of representative games to broaden the span of possible solutions. This should ultimately help them make their own decisions in formal games. Through this variability, they discover which solutions are relevant and appropriate to situations, constraints, stakes, or even states of their body and mind, all being different variables that they could experiment through their pathway. Just as any skill, time and repetitions can transform abilities and solutions in competencies as long as they are put to practice in an environment that allows and promotes them. Along with training, solutions can be refined with feedback or exchanges to refine them and transfer them back into the play. ${ }^{32}$

\section{Creativity}

Creativity involves all characteristics of intelligence and the ability to execute novel and innovative movements to reach the objective of the game. ${ }^{33,34}$ For this reason, creativity is increasingly identified as one important quality to develop yet from a young age, through holistic approaches to develop thinking abilities for a review, see. ${ }^{35}$ As illustrated by the authors of the review, creativity allows the player to exploit more available possibilities in an unpredictable and varying environment, employing convergent and divergent thinking. The authors support the development of both modes as a blend that will potentialize physical literacy and the experience of a wide range of situations.

In a study about tactical knowledge, it was observed that older players would perform better the actions associated with converging and diverging thinking compared to younger players. ${ }^{36}$ Assuming that older players do have more experience, it is possible that they have accumulated more resources to show creativity when appropriate. These age aspects are in line with specialization ages identified in the review once creativity is seen as a competency observed in players judged as experts. ${ }^{35}$ To reach such discernment, authors also argue that players should be allowed to use a freer creativity through naïve free-play and deliberate play and expand their range of skills, which is the case of the famous street football. ${ }^{37}$

Creativity is associated with knowledge and cognitive and technical skills since they reflect the necessary experience to make divergent or convergent decisions. With respect to cognitivist theories, these decisions will also depend on their ability to recall previous experiences and explore more possibilities of action depending on what has resulted in before. ${ }^{10}$. On the other hand, exploring new possibilities will also depend on their availability. Thus, creativity will be manifested in environments rich in stimuli and variability but are not necessarily bound with too many rules. Favoring and stimulating 
learning/training activities like SSCGs based on a few broad rules can provide a dose of freedom, as long as they are designed accordingly.

This reinforces the use of SSCGs as practical activities to develop creativity. ${ }^{38}$ As long as their design provides the appropriate challenges and the needed representativeness to overcome competition's difficulties throughout progression, SSCGs can be considered a viable, representative environment to develop competencies. In such an environment, players should be able to develop their creative side if promoted, encouraged to do so, or should stick to expected actions and their immediate results. Nevertheless, given the non-linear nature of learning pathways, players will develop skills according to their experience but should pull out most of the environment if creativity is valorized.

\section{Co-adaptation and self-organization}

Since the play involves more than one player, competencies can also consist of shared resources that help players play together in synchronicity. Accordingly, concepts of shared resources pinpoint how competencies can serve players individually but also the connection between players. ${ }^{17}$ However, another perspective on the phenomenon can be explored to explain players'organization, such as taking advantage of shared opportunities and the flexible application of play principles. ${ }^{39,40}$ Such concepts portray how tactical actions can be performed according to the positioning of teammates and opponents. The growing interest for adaptiveness and auto-organization reinforces the importance of possibilities of play in environments that require to coordinate actions with teammates and opponents, yet from a young age for a review, see. ${ }^{41}$

Recent practical propositions in the field of training put forward the use of constraints and appropriate design of context in the play to leave room for more adaptation.42,43,44 Thus, by changing manipulating constraints and changing games'parameters, coaches can vary the complexity and the difficulty of the tasks while maintaining the core functionality of the game and the room to apply principles of play. ${ }^{45}$ In addition, making it more difficult - or easier - for players to succeed, also allow them to explore self-organization and co-adaptation to new play situations. As players and groups of players will experiment with problems, they have to regulate their decisions concerning teammates, synchronize through principles, and auto-organize. Such tasks are identified as a required collective capability before tackling the game model, given that its constraints stem from guidelines rather than from the play itself. ${ }^{41}$

Ultimately, the ability to co-adapt to the situations of play and to changing teammates/opponents translates in competency when players are constantly required to read, decide and adapt, and when they can rely on principles while deciding what to do and to solve situations. Even if they have short-term results, pre-determined schemes and directives should rather limit the span of solutions and consequently hold players' longterm development.

\section{IMPLICATIONS AND CONCLUSION}

For all the reasons evoked earlier, tactical intelligence and creativity can be useful to players as they respectively reflect the ability to solve a problem and to find an unusual solution. ${ }^{10}$ In more detail, the intelligent player masters more technical-tactical solutions and can choose the best one. In contrast, the creative player shows flexibility and 
variability in the solutions he chooses to execute. ${ }^{46}$ On its end, co-adaptability helps players complete one another without necessarily having rehearsed movements or combinations before. ${ }^{44}$

As performing players seek to find solutions in all contexts and games, developing players should be directed to build their experience of the play around the three competencies since such qualities should lead them to adapt to the situation-problems and solve them efficiently and effectively. Tactical problems, referred to as situation-problems, are repeatedly found in SSCGs. The purpose of playing small-scaled games is to repeatedly expose players to particular situations and conditions that reflect key aspects of competitive performance. ${ }^{47,48}$ Thus, these games are commonly utilized and recommended as representative exercises, and their usage is reported in more studies in contemporary literature to nurture tactical competencies. ${ }^{18}$

Nevertheless, these tactical competencies are developed through the repeated experience of situation-problems as long as they vary and are adequately designed. Players will also develop these key qualities to respond to higher demands of performance. They need to find new solutions when facing the changing nature of the play and its arising problems in increasing competition levels. When conceived as the task at hand, solving tactical problems requires highly developed competencies such as the ones explored in this paper and the associated activities to develop them.

Whilst using a SSCG tournament, Silva and his collaborators ${ }^{4}$ found that the firstranked teams performed more offensive tactical actions and were more efficient at performing them than second-and third-ranked teams. In addition to being more proactive as they created the play, winners were also more effective in offensive and defensive actions, giving their own team an advantage in more situation-problems. In respect with the competencies that help take over opponents, the authors suggest that this performing behavior was a demonstration of giving an accurate reading of the play situations. As a result, the players of the same team in SSCGs would then decide and perform better individually as much as they would have shown a better collective readiness to co-adapt and organize themselves. ${ }^{49}$ In addition to intelligence and creativity, co-adaptability becomes an important competency to develop to enhance tactical behavior.

In conclusion, coaches can then use SSCGs to propose situation-problems of play to solicit problem-solving repeatedly with the objective to mold players' tactical behavior or instill qualities in their play. Such activities can also help scouts identify talent or prospect recruits to competitive squads, just as it can help direct the program curriculum. Literature increasingly shows that SSCGs can stimulate the development of performing players, including the key competencies that will help them perform in a wider span of situationproblems in the play throughout their career. Players that show all qualities in addition to intelligence, creativity, and co-adaptability will more probably be performing in more different places than other players. With the interest of development being the endproduct, this paper shows the importance and potential of leading more players to build around such qualities in a long-term player development ideology.

\section{REFERENCES}

1. Kannekens R, Elferink-Gemser MT, Visscher C. Tactical skills of world-class youth soccer teams. J Sport Sci. 2009 Jun 1;27(8):807-12. doi: 10.1080/02640410902894339

\begin{tabular}{l|l|l|l|ll}
\hline $\begin{array}{l}\text { Petiot, Silva, } \\
\text { Ometto }\end{array}$ & 2020 & VOL.14 & N.5 & https://doi.org/10.20338/bjmb.v14i5.199
\end{tabular}


2. Gonet DT, Castellano J, Vasconcellos FV. Effect of a 35 week soccer training program based on game based approach on the physical and attentional capacity of children and adolescents. EJPESS. 2020;6. doi: 10.46827/ejpe.v6i7.3312

3. Carvalho FM, Scaglia AJ, Costa ITD. Influência do desempenho tático sobre o resultado final em jogo reduzido de futebol. Rev. educ. fis. UEM. 2013;24:393-400. doi: 10.4025/reveducfis.v24.3.18902

4. Silva D, Costa VT, Casanova F, Clemente FM, Teoldo I. Comparison between teams of different ranks in small-sided and conditioned games tournaments. Int J Perf Anal Spor. 2019:1-16. doi: 10.1080/24748668.2019.1643598

5. Teoldo I, Guilherme J, Garganta J. Training football for smart playing: on tactical performance of teams and players. Editora Appris; 2017.

6. Garganta J, Guilherme J, Barreira D, Brito, J, Rebelo A. Fundamentos e práticas para o ensino e treino do futebol. In: Tavares $\mathrm{F}$ (ed) Jogos Desportivos Coletivos Ensinar a jogar. Porto: Faculdade de Desporto da U. Porto (FADEUP); 2013:pp.199-263.

7. Silva P, Chung D, Carvalho T, Cardoso T, Davids K, Araújo D, et al. Practice effects on intra-team synergies in football teams. Hum Movement Sci. 2016;46:39-51. doi: 10.1016/j.humov.2015.11.017

8. Den Hartigh RJ, Van Der Steen S, Hakvoort B, Frencken WG, Lemmink KA. Differences in game reading between selected and non-selected youth soccer players. J Sport Sci. 2018;36:422-428. doi: 10.1080/02640414.2017.1313442

9. Ferrari R. Writing narrative style literature reviews. Medical Writ. 2015;24:230-235. doi: 10.1179/2047480615Z.000000000329

10. Da Silva Matias CJA, Greco PJ. Cognição \& ação nos jogos esportivos coletivos. Ciênc. cogn. 2010;15:pp. 252-271.

11. Williams AM, Hodges NJ, North JS, Barton G. Perceiving patterns of play in dynamic sport tasks: Investigating the essential information underlying skilled performance. Perception. 2006;35:317. doi: 10.1068/p5310

12. North JS, Williams AM, Hodges N, Ward P, Ericsson KA. Perceiving patterns in dynamic action sequences: Investigating the processes underpinning stimulus recognition and anticipation skill. Appl Cognitive Psych. 2009;23:878-894. doi: 10.1002/acp.1581

13. González Víllora S, Serra-Olivares J, Pastor-Vicedo JC, Teoldo Da Costa I. Review of the tactical evaluation tools for youth players, assessing the tactics in team sports: football. Springerplus. 2015;663. doi: 10.1186/s40064-015-1462-0.

14. Garganta J. Modelação táctica do jogo de futebol: Estudo da organização da fase ofensiva em equipas de alto rendimento. 1997.

15. Forsman H, Blomqvist M, Davids K, Liukkonen J, Konttinen N. Identifying technical, physiological, tactical and psychological characteristics that contribute to career progression in soccer. Int J Sport Sci Coa. 2016 Aug;11(4):505-13. doi: $10.1177 / 1747954116655051$ 
16. Araújo D. O desenvolvimento da competência táctica no desporto: o papel dos constrangimentos no comportamento decisional. Motriz rev educ fís (Impr). 2009;15:537540 .

17. Gréhaigne J-F. L'intelligence tactique: Des perceptions aux décisions tactiques en sports collectifs. Besançon: Presses universitaires de Franche-Comté; 2014.

18. Clemente FM. Small-sided and conditioned games in soccer training: the science and practical applications. Singapore: Springer; 2016 Mar 31.

19. Roca A, Ford PR. Decision-making practice during coaching sessions in elite youth football across European countries. Sci Med Football. 2020 Apr 19:1-6. doi: 10.1080/24733938.2020.1755051

20. Garganta J. Dos constrangimentos da acção à liberdade de (inter) acção, para um Futebol com pés... e cabeça. O contexto da decisão-A acção táctica no desporto. 2005:179-190.

21. Marasso D, Laborde S, Bardaglio G, Raab M. A developmental perspective on decision making in sports. Int Rev Sport Exer P. 2014;7:251-273. doi: 10.1080/1750984X.2014.932424

22. Raab M, Gigerenzer $G$. The power of simplicity: a fast-and-frugal heuristics approach to performance science. Front Psychol. 2015;6. doi: 10.3389/fpsyg.2015.01672

23. Almeida $\mathrm{CH}$, Ferreira AP, Volossovitch A. Offensive sequences in youth soccer: effects of experience and small-sided games. J Hum Kinet. 2013;36:97-106. doi: 10.2478/hukin2013-0010

24. Raab M, Johnson JG. Implicit learning as a means to intuitive decision making in sports. Intuition in judgement and decision making. 2008:119-133.

25. De Montmollin M. Savoir travailler. Le point de vue de l'ergonome. Education et formation. 2011:189-199.

26. Musculus $L$, Raab M, Belling $P$, Lobinger $B$. Linking self-efficacy and decision-making processes in developing soccer players. Psychol Sport Exerc. 2018;39:72-80. doi: 10.1016/j.psychsport.2018.07.008

27. Hanin YL. Emotions in sport: Current issues and perspectives. Handbook of sport psychology. 2007;3:22-41.

28. Raab M, Lobinger B, Hoffmann S, Pizzera A, Laborde S. Performance psychology: Perception, action, cognition, and emotion. Academic Press; 2015.

29. Vorraber GA. Análise dos processos cognitivo-afetivos inerentes ao desempenho táticoesportivo. Revista Brasileira de Terapias Cognitivas. 2010;6:118-141. doi: 10.5935/18085687.20100018

30. Gonzaga ADS, Albuquerque MR, Malloy-Diniz LF, Greco PJ, Teoldo I. Affective decisionmaking and tactical behavior of under-15 soccer players. PloS one. 2014;9:e101231. doi: 10.1371/journal.pone.0101231.

31. Laborde S, Raab M, Dosseville F. Emotions and performance: Valuable insights from the sports domain. 2013. 
32. Moxley JH, Ericsson KA, Charness N, Krampe RT. The role of intuition and deliberative thinking in experts' superior tactical decision-making. Cognition. 2012;124:72-78. doi: 10.1016/j.cognition.2012.03.005

33. Damásio A. O sentimento de si: o corpo, a emoção e a neurobiologia da consciência. Publ. Europa-América; 2003.

34. Samulski D, Costa V. Criatividade: uma visão multidisciplinar. Samulski, D. Psicologia do esporte: um manual para Educação Física, Psicologia e Fisioterapia. São Paulo: Manole. 2002:319-345.

35. Santos SD, Memmert D, Sampaio J, Leite N. The spawns of creative behavior in team sports: A creativity developmental framework. Front Psychol. 2016;7:1282. doi: 10.3389/fpsyg.2016.01282

36. Giacomini DS, Soares VO, Santos HF, Matias CJ, Greco PJ. Declarative and procedural tactical knowledge in soccer players of different ages. Motricidade. 2011;7:43.

37. Machado JC, Barreira D, Galatti L, Chow JY, Garganta J, Scaglia AJ. Enhancing learning in the context of Street football: a case for Nonlinear Pedagogy. J Phys Educ Sport Peda. 2018:1-14. doi: 10.1080/17408989.2018.1552674

38. Caso S, Van Der Kamp J. Variability and creativity in small-sided conditioned games among elite soccer players. Psychol Sport Exerc. 2020;48:101645. doi: 10.1016/j.psychsport.2019.101645

39. Da Costa IT, Da Silva JMG, Greco PJ, Mesquita I. Tactical principles of Soccer: concepts and application. Motriz. 2009;15:657-668.

40. Silva P, Garganta J, Araújo D, Davids K, Aguiar P. Shared knowledge or shared affordances? Insights from an ecological dynamics approach to team coordination in sports. Sports Med. 2013;43:765-772. doi: 10.1007/s40279-013-0070-9

41. Ribeiro J, Davids K, Araújo D, Guilherme J, Silva P, Garganta J. Exploiting Bi-Directional Self-Organizing Tendencies in Team Sports: The Role of the Game Model and Tactical Principles of Play. Front Psychol. 2019;10. doi: 10.3389/fpsyg.2019.02213.

42. Davids KW. The constraints-based approach to motor learning: implications for a nonlinear pedagogy in sport and physical education. Motor learning in practice: A constraints-led approach. Routledge (Taylor \& Francis Group); 2010:pp.3-16.

43. Davids KW, Button C, Bennett SJ. Dynamics of skill acquisition: A constraints-led approach. Human Kinetics; 2008.

44. Davids K, Araújo D, Correia V, Vilar L. How small-sided and conditioned games enhance acquisition of movement and decision-making skills. Exerc Sport Sci Rev. 2013;41:154161. doi: $10.1097 / J E S .0 b 013 e 318292 f 3 e c$

45. Machado JC, Barreira D, Teoldo I, Travassos B, Júnior JB, Santos JO, Scaglia AJ. How Does the Adjustment of Training Task Difficulty Level Influence Tactical Behavior in Soccer? Res Q Exercise Sport. 2019:1-14. doi: 10.1080/02701367.2019.1612511

46. Memmert D, Roth K. The effects of non-specific and specific concepts on tactical creativity in team ball sports. J Sport Sci. 2007;25:1423-1432. doi 10.1080/02640410601129755 
47. Ometto L, Vasconcellos FV, Cunha FA, Teoldo I, Souza CRB, Dutra MB, et al. How manipulating task constraints in small-sided and conditioned games shapes emergence of individual and collective tactical behaviours in football: A systematic review. Int J Sport Sci Coa. 2018;13:1200-1214. Doi: 10.1177/1747954118769183

48. Sarmento H, Clemente FM, Harper LD, Costa ITD, Owen A, Figueiredo AJ. Small sided games in soccer-a systematic review. Int J Perf Anal Spor. 2018;18:693-749. doi: 10.1080/24748668.2018.1517288

49. Moreira PE, Barbosa GF, Murta CD, Pérez Morales JC, Bredt SD, Praça GM, Greco PJ. Network analysis and tactical behaviour in soccer small-sided and conditioned games: Influence of absolute and relative playing areas on different age categories. Int J Perf Anal Spor. 2020;20:64-77. doi: 10.1080/24748668.2019.1705642

Citation: Petiot GH, Silva D, Ometto L. Exploring key competencies sought to potentialize tactical behavior in soccer players. BJMB. 2020: 14(5):157-166.

Editors: Dr Fabio Augusto Barbieri - São Paulo State University (UNESP), Bauru, SP, Brazil; Dr José Angelo Barela - São Paulo State University (UNESP), Rio Claro, SP, Brazil; Dr Natalia Madalena Rinaldi - Federal University of Espírito Santo (UFES), Vitória, ES, Brazil.

Guest Editors: Dr Rodrigo Aquino - Federal University of Espírito Santo (UFES), Vitória, ES, Brazil; Ms Luiz H Palucci Vieira - São Paulo State University (UNESP), Bauru, SP, Brazil; Dr Filipe Manuel Clemente - Escola Superior Desporto e Lazer, Instituto Politécnico de Viana do Castelo, Melgaço, Portugal; Dr João Cláudio Braga Pereira Machado -Federal University of Amazonas (UFAM), Manaus, AM, Brazil; Dr Gibson Moreira Praça - Universidade Federal de Minas Gerais (UFMG), Belo Horizonte, MG, Brazil Copyright:@ 2020 Petiot, Silva and Ometto and BJMB. This is an open-access article distributed under the terms of the Creative Commons Attribution-NonCommercial-NoDerivatives 4.0 International License which permits unrestricted use, distribution, and reproduction in any medium, provided the original author and source are credited.

Funding: There was no funding for this study.

Competing interests: The authors have declared that no competing interests exist.

DOl:https://doi.org/10.20338/bjmb.v14i5.199 